

\section{SAND78-8045}

Unimited Release

Printed March 1979

PLATING ON ZIRCALOY-2

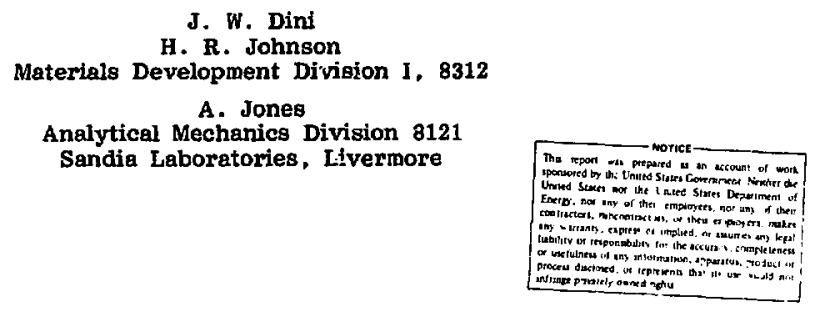

ABSTRACT

Zircaloy-2 is a difficult alloy to coat with an adherent electroplate because it easily forms a tenacious oxide film in air and equeous solutions. Procedures reported in the literature and those developed at SLL for ourmounting this problem were investigated. The best results were obtained when specimens were first etched in either an ammonium bifluoride/sulfuric acid or an ammonium bifluoride solution, plated, and then heated at $700 \mathrm{C}$ foi 1 hour in a constrained condition. Machining threads in the Zircaloy-2 for the purpose of providing sites for mechanical interlocking of the plating also proved satisfactory. 


\section{ACKNOWLEDGMENTS}

We would like to thank the following people for their raluable assistance on this work: Dez Brown (8312) for plating support, Mike Nash (8313) for testing, Tom Bryant (8312) for metallography, and Bob T'ucker (8265) for technical editing.

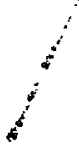


Introduction

Review of the Literature

Test Procedures

Results

A. As Deposited

12

B. After Heating

13

C. Mechanical Treatmente

16

Summary

17

References

19 


\section{ILLUSTRATIONS}

Figure

1. Schematic of Parts

2. Radial Stresses as a Function of Radius for a $\mathrm{Zr}-\mathrm{Ni}-\mathrm{Mo}$ Composite at $700 \mathrm{C}$

3. Cross Section of a Zircaloy Rod Machined With 20 Threads $/ \mathrm{cm}, 0.13 \mathrm{~mm}$ Deep, Overplated With Thin Chromium and Thick Nickel, and Then Tested

\section{TABLES}

I. Ring Shear Data for Chemical Activation Treatments for Zircaloy-2

I1. Composition and Operating Conditions for Nickel Sulfamate Solution

III. Properties of the Materials Used in Differential Thermal Analysis

IV. Influence of Heating on the Ring Shear Strength. of Nickel-Plated Zircaloy-2

v. Ring Shear Data for Mechanical Preparation Treatments for Zircaloy -2 


\title{
PLATING ON ZIRCALOY-2
}

\author{
Introduction
}

Zirconium is one of a group of metals including $\mathrm{Be}, \mathrm{Al}, \mathrm{Ti}, \mathrm{Nb}, \mathrm{Mo}, \mathrm{Th}$, and $U$, whose properties are important in certain nuclear applications. Like many of these metals, zirconium's surface properties are such that soldering and brazing to a second metal are difficult. Coating the airconium with another metal by electroplating has sometimes been used to surmount this difficulty. Schickner, Beach, and Faust ${ }^{1}$ have shown that nickel electroplates on $\mathrm{Zr}$ can withstand a coldering operation.

However, zirconium is a difficult metal on which to make an adherent plating beccuse it forms a tenacious oxide very quiokly in air. Although the thickness of this oxide is probably less than $25 \mathrm{~A}, 2$ it renders the metal quite passive. In this regaid zirconium is not unlike $B e, A 1, M_{B}$, and atainless steels, all of which require special activation treatments if a plating is to be adherent.

At Sandia we have had considerabie experience joining metals by plating when other means were difficult to use. 3,4 In one particular application it was necessary to join zirconium and stainless steel. The desired service temperature was around $350 \mathrm{C}$, and silver brezing did not produce acceptable results. It was therefore decided to investigate a number of plating procedures with the ultimate goal being to provide a capability for joining zirconium to other metals by plating:

\section{Review of the Literature}

The literature on plating on zirconium is relatively sparse. Researchers at Battelle Columbus Laboratories have been the most prolific in this area, 1,5-7. Schickner, Beach, and Faust ${ }^{1}$ utilized a procese consisting of chemical polishing followed by etching in ammonium bifluoride/hydrofluoric acid solution prior to nickel plating. For best bonding, parts were then prebaked at $200 \mathrm{C}$ for 2 to 4 hours and then heated at $700 \mathrm{C}$ for 10 to 45 minutes. Other metals could then be deposited on the nickel. Another technique they used consisted of applying an immersion zinc plate by dipping zirconium for 1 minute in molten zine chloride at 440 to $450 \mathrm{C} .5$ Silver soldering of a brass rod to the zinc-coated zirconium resulted in a joint that did not fail until after the rod was severely bent. Tripler, Beach, and Faust? studied methods of coating zirconium with platinum for the purpose of decreasing the corrosion in uranyl sulfate solutions. The 
chemical polishing procedure followed by the ammonium bifluoride/hydrofluoric acid etch discussed above was used with subsequent diffusion bonding.

Huddle and Flint ${ }^{8}$ prepared zixconium for plating by shot blasting and then immersing it in a solution of copper sulfate, aluminum sulfate, and sulfuric acid. The inmersion copper film formed by this process could then be plated over. with other metals. Chorveriat ${ }^{9}$ protected zirconium and its alloys by applying a chromium deposit from a solution containing chromic acld, strontium sulfate, and potassium fluasilicate. He cloimed improved adhegion and ductility of this coating by vacuum heating at 700 to $850 \mathrm{C}$. Kneip and Turnbaugh 10 patented a procedure for copper plating on Zr-Nb alloys, with HF, ferric chloride, and nickel chloride. Saubestref utilized the "hydride plating process", which consists of room-temperature cathodic treatment for 5-15 Beconds at $108-1080 \mathrm{~A} / \mathrm{m}^{2}$ $(10-100$ asf $)$ in electrolytes such as $28(w t.) \mathrm{HCl}, \mathrm{H}_{2} \mathrm{SO}_{4}, \mathrm{HNO}_{3}, \mathrm{HF}, \mathrm{KOH}$, or $\mathrm{NaOH}$.

Kohan 12 described the immersion plating of Zircaloy-2 with copper, iron, tin, or nickel in solutions containing hydrofluoric acid. Very recently, Wax and Cowan 13 patented the use of solutions comprised of dilute amounts of ammonium bifluoride and sulfuric acid for activating zirconium for plating.

\section{Test Procedures}

The material used was Zircaloy-2 in the shape of 1.27 -cm-diameter rods.* Several procedures, for which the detailed formulations and conditions are listed in Table I, were evaluated. Quentitative data were obtained for these processes by use of ring shear tests. These consisted of coating the rods with separate rings of plating of predetermined width and then forcing the specimen through a hardened steel die having a hole larger in diameter than the rod but less than that of the rod plus coating. The area of the test specimen and the load required to cause failure were used to calculate strength. Complete details on ring shear sample preparation and test procedures have been described elsewhere. 14-1j Uniess otherwise mentioned, nickel deposited from a sulfamate solution (Table II) was used for the coating we were trying to deposit adherently on the Zircaloy.

Based on the results of this phase of the program, some samples were then prepared for heat treatment studies to determine if this would help improve adhesion. In addition, other samples were given mechanical treatments such as threading or knurling for the purpose of increasing surface area of the Zircaloy.

Zircaloy-2 contains $1.5 \mathrm{Sn}, 0.12 \mathrm{Fe}, 0.10 \mathrm{Cr}, 0.05 \mathrm{Ni}, 0.01 \mathrm{O}$, with the belance $\mathrm{Zr}$. 
TABLE I

RING SHEAR DATA FOR CHEMICAL ACTIVATION TREATMENTS FOR ZIRCALOY-2

\begin{tabular}{|c|c|c|c|c|}
\hline Description & Reference & Procegs & $\frac{\text { Ring Shear }}{\left(\mathrm{MN} / \mathrm{m}^{2}\right)}$ & $\frac{\text { Strenth }}{\text { (poli) }}$ \\
\hline Ammonium Billuoride & 1 & Etch in $40 \mathrm{~g} / 1$ ammonium bifluaride, $3 \mathrm{~min}$ at $22 \mathrm{C}$ & $\begin{array}{r}81 \\
31 \\
6\end{array}$ & $\begin{array}{r}11,800 \\
4,500 \\
800\end{array}$ \\
\hline $\begin{array}{l}\text { Ammonlum Bifluoride/ } \\
\text { Sulfuric Acid }\end{array}$ & 13 & $\begin{array}{l}\text { Etoh in } 15 \mathrm{~g} / 1 \text { ammonium bifluoride, } 1 / 2 \mathrm{ml} / 1 \text { sulfuric acid, } \\
1 \mathrm{~min} \text { at } 22 \mathrm{C}\end{array}$ & $\begin{array}{l}78 \\
25 \\
15\end{array}$ & $\begin{array}{r}11,400 \\
3,600 \\
2,100\end{array}$ \\
\hline $\begin{array}{l}\text { Ammonium Bifluoride/ } \\
\text { HF }\end{array}$ & 1 & Etch in $50 \mathrm{~g} / 1$ ammoni am bifluarte, 5 min at $50 \mathrm{C}$ & $\begin{array}{l}17 \\
31\end{array}$ & $\begin{array}{l}2,500 \\
4,500\end{array}$ \\
\hline Copper Nitrate/HF & 12 & Immerse in $50 \mathrm{~g} / 1$ copper nitrate, $3 \mathrm{ml} / 1 \mathrm{HF}, 37 \mathrm{C}, 1 \mathrm{hr}$ & 39 & 5,700 \\
\hline Sodium Hydroxide & - & Use anodic oxidation in $100 \mathrm{~g} / 1 \mathrm{NaOH}$ at $5 \mathrm{~V}, 10 \mathrm{~min}, 25 \mathrm{C}$ & 37 & 5,300 \\
\hline $\begin{array}{l}\text { HF, Ferric Chloride, } \\
\text { Nickel Chloride }\end{array}$ & 10 & $\begin{array}{l}\text { Pickle in } 100 \mathrm{ml} / 1 \mathrm{HF}, 4 \mathrm{~g} / 1 \text { ferric chloride, } 3 \mathrm{~g} / 1 \text { nickel } \\
\text { chloride, } 20 \mathrm{~g} \text { at } 22 \mathrm{C} \text {; then use copper strike before final } \\
\text { plating }\end{array}$ & 48 & 7,000 \\
\hline lonitech Process & 16 & $\begin{array}{l}\text { Pickle in } 200 \mathrm{ml} \mathrm{HNO}_{3}, 100 \mathrm{ml} \mathrm{H}_{2} \mathrm{SO}_{4}, 100 \mathrm{ml} \mathrm{H}_{2} \mathrm{O}, 45 \mathrm{~g} \\
\text { actane 70, } 5 \mathrm{~min} \text {; then immerse in } 20 \% \mathrm{HNO}_{3} \text { at } 80 \mathrm{C} \text { prior } \\
\text { to nickel plating }\end{array}$ & 26 & 3,800 \\
\hline Wood'g Nickel & 17 & Use Wood's nickel strike, cathodic, 5 min at $540 \mathrm{~A} / \mathrm{m}^{2}$ & 23 & 3,300 \\
\hline $\mathrm{H}_{2} \mathrm{SO}_{4} / \mathrm{WoOd}^{\mathrm{t}} \mathrm{s}$ Nickel & - & $\begin{array}{l}\text { Use anodic oxidation in } 70 \% \text { (wt.) } \mathrm{H}_{2} \mathrm{SO}_{4}, 3 \text { min at } 1080 \mathrm{~A} / \mathrm{m}^{2} \\
\text { followed by Wood' } \mathrm{B} \text { nickel, cathodic, } 5 \mathrm{~m} \text { in at } 540 \mathrm{~A} / \mathrm{m}^{2}\end{array}$ & 17 & 2,500 \\
\hline Cobalt Sulfate Strike & 18 & $\begin{array}{l}\text { Etch in } 50 \mathrm{~g} / 1 \text { ammonium bifluorice, } 30 \mathrm{ml} / \mathrm{L} \mathrm{HF}, 5 \mathrm{~min} \text { at } \\
50 \mathrm{C} \text {, gtrike in } 200 \mathrm{~g} / 1 \mathrm{CoSO}_{4} \cdot 7 \mathrm{H}_{2} \mathrm{O}, 90 \mathrm{ml} / 1 \mathrm{H}_{2} \mathrm{SO}_{4} \text { at } \\
22 \mathrm{C} \text {. } 5 \mathrm{~min} \text { at } 540 \mathrm{~A} / \mathrm{m}^{2}\end{array}$ & 22 & 3,200 \\
\hline $\begin{array}{l}\text { Ammonium Btfluoride/ } \\
\text { Wood's Nickel }\end{array}$ & - & $\begin{array}{l}\text { Etch in } 45 \mathrm{~g} / 1 \text { ammonium bifluoride, } 3 \mathrm{~min} \text { at } 22 \mathrm{C} \text {, then } 50 \% \\
\mathrm{HNO}_{3}, 3 \mathrm{~min} \text {, then Wood's nickel. } 5 \mathrm{~min} \text { at } 540 \mathrm{~A} / \mathrm{m}^{2}\end{array}$ & 10 & 1,500 \\
\hline Sydride Procegs & 11 & $\begin{array}{l}\text { Etch in } 10 \% \mathrm{HF}, 2 \mathrm{~min} \text {; cathodic for } 15 \mathrm{~s} \text { at } 1080 \mathrm{~A} / \mathrm{m}^{2} \text { in } \\
2 \mathrm{~g} / 1 \mathrm{~N}_{\mathrm{g}} \mathrm{OH}\end{array}$ & 10 & 1,500 \\
\hline
\end{tabular}

Bach value is the average of at legst three teste. All specimens were overplated with alckel

using the cormulation and conditions listed in Table I. 
Nickel (as nickel sulfamate*)

Nickel chloride

Boric acid

Surface tension

pH

Anodes

Current density

Temperature
$81 \mathrm{~g} / 1$

$<1.0 \mathrm{~g} / 1$

$40 \mathrm{~g} / 1$

38 dyne/cm

$3.8-4.0$

Sulfur depolarized

$215 \mathrm{~A} / \mathrm{m}^{2}$

$49 \mathrm{C}$

\section{* MeT Chemicals, Rahway, NJ}

\section{Results}

\section{A. As Deposited}

The data for the chemical activation treatments which resulted in adhesion measurable by the ring shear test are presented in Table $\mathrm{I}$. The best results-$81 \mathrm{MN} / \mathrm{m}^{2}$ (11,800 psi)--were obtained when specimens were etched in ammoniutn bifluoride solution prior to nickel plating. However, the data for these were inconsistent inasmuch as values ranging from 6 to $81 \mathrm{MN} / \mathrm{m}^{2}$ were obtained. Activation in a solution containing HF, ferric chloride, and nickel chloride gave good results $\left(48 \mathrm{MN} / \mathrm{m}^{2}\right)$. All the other tecinniques resulted in strengths less than $40 \mathrm{MN} / \mathrm{m}^{2}$. For comparison, the ring shear strength of solid $\mathrm{Zr}-2$ is $362 \mathrm{MN} / \mathrm{m}^{2}$.

Other processes evaluated were anodic treatment in concentrated $\mathrm{HCl}$, immersion in ferzic ehloride/HF, anodic treatment in ammonium bifluoride/HF prior to chromium plating, and anodic treatment in an iodine/methanol solution. They were not effective. Ring shear specimens could not be successfully machined from specimens given these treatments prior to plating, thus indicating that the plating-substrate bond spas essentially nonexistent.

Although the results with ammonium bifluoride were uneven, additional work was done with this etchant since it offered more promise for use in production because of its simplicity when compared to the other processes listed in Table II. 


\section{B. After Heating}

Other workers have reported on the beneficial effects of diffusion to improve adherence.1-6 Based on their work, specimens were activated in ammonium bifluoride, nickel plated, and then heated in vacuum at $700 \mathrm{C}$ in both constrained and unconstrained conditions. One set of constrained specimens were pleced in a TZM molybdenum ring during heating. Since the coefficient of thermal expansion for molybdenum is lower than that of zirconium or nickel, it provided a stress on the plating as the assemblies were heated. Zanner and Fisher 19 used this approach to bond bronze successfully to a titanium alloy.

Because of the importance of this technique, an analysis was made of the differential thermal constraint of the $\mathrm{Zr}-\mathrm{Ni}$-Mo composite. The problem, shown schematically in Figure 1 , is one of concentric cylinders with clearance gaps closing with increasing temperature, thereby producing compressive stress at the bond line. The material properties that were used for the calculation are listed in Table III. A finite element analysis was done in which the cylinders were uniformly heated in stepe to $700 \mathrm{C}$. The zero-stress temperature was 25 C. The clearance for this problem must be very small to produce a substantial compression at the bond. For calculational purposes, initial clearances were varied from 0 (no clearance) to 50 um (for this value, contact between the cylinders did not take place at $700 \mathrm{C}-$-see Figure 2).

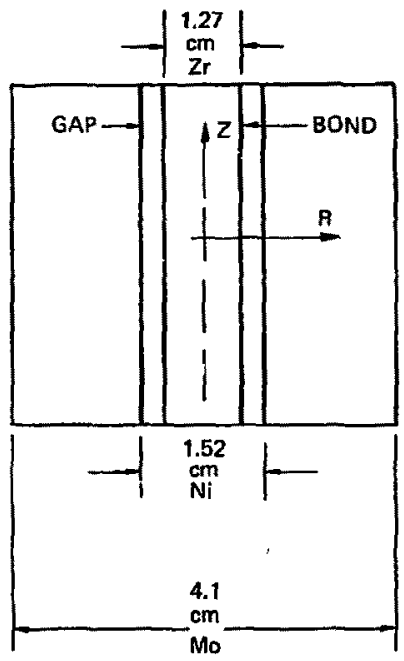

Figure 1. Schematic of Parts 
TABLE III

PROPERTIES OF THE MATERIALS USBD IN DIFFERENTIAL THERMAL ANALYSIS

Coefficient of Linear

Thermal Expansion $\left(10^{-6} \mathrm{~cm} / \mathrm{cm}{ }^{\circ} \mathrm{C}\right)$

Modulus of Blasticity

\begin{tabular}{lcc} 
& $\left(10^{-6} \mathrm{~cm} / \mathrm{cm}{ }^{\circ} \mathrm{C}\right)$ & $\left(10^{4} \mathrm{MN} / \mathrm{m}^{2}\right)$ \\
\hline & & \\
Wi & 15.0 & 172 \\
Mo & 5.4 & 324 \\
$\mathrm{Zr}$ & 8.0 & 95 \\
\hline
\end{tabular}

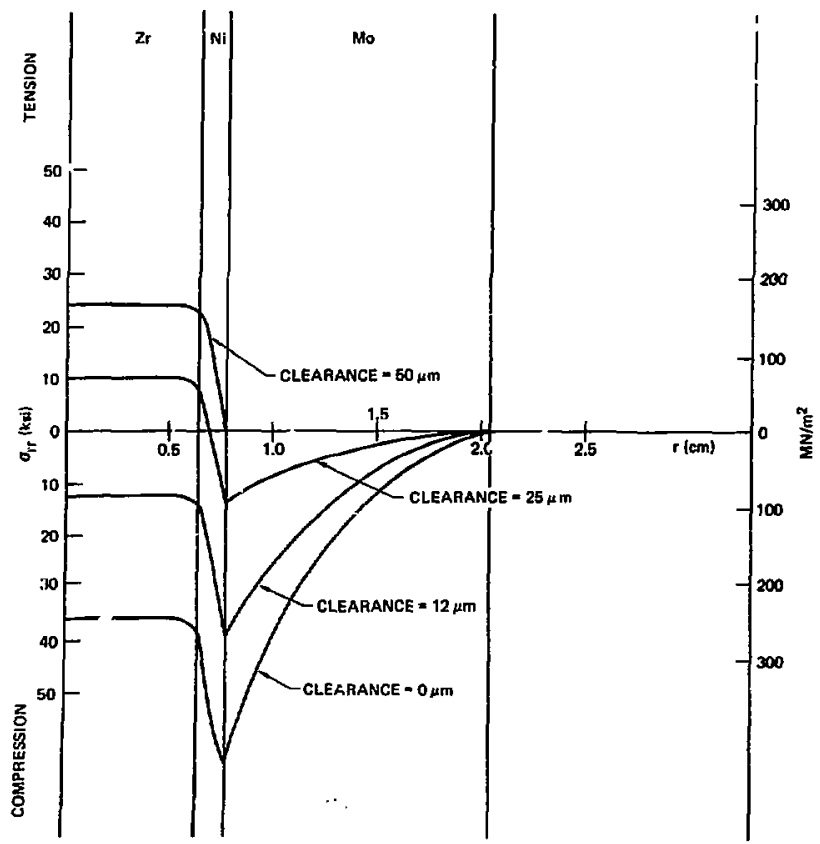

Figure 2. Radial Stresses as a Function of Radius for a Zr-Ni-Mo Composite at $700 \mathrm{C}$ 
Several pointe are worth noting. (1) The stresses at the drcontum-nlekel interface are oniy compressive for a very tight fit (initlel clearances less than $25 \mathrm{\mu m}$ ). (2) The maximum compresalve atress that can be developed is about $262 \mathrm{mN} / \mathrm{m}^{2}(36,000 \mathrm{psi})$ with a perfect initial fit. Larger starting clearances than this produce a reduced bond stress. (3) Tensile atresses can be present in the joint even with some interference. For example, refer to the 25-un curve in Aigure 2, in which $\sigma_{\mathrm{rr}}>0$ for $\mathrm{x}<0.69 \mathrm{~cm}$. This is caused by the mickel expanding away from the zrconium. (4) For any initial nonzero cleararıce, as the temperature increases and while the cyllnders are not in oontact, the inner cylinder will develop tensile atress at the bond interface.

Results of the heating experiments are presented in Table IV. The data clearly show a noticeable improvement as a result of heating for specitoens which were constrained during heating (the clearance between the cylinders and the Mo die was $25 \mu \mathrm{m}$ or less for all of this work). Bond strengths around $240 \mathrm{MN} / \mathrm{m}^{2}$ were obtained for a number of specimens. For comparison purposes, the shear strength of electroformed sulfamate nickel after heating at $700 \mathrm{C}$ for 1 hour is $310 \mathrm{mN} / \mathrm{m}^{2}$.

TABLE IV

WFLUENCE OF HEAT TNG ON THE ARIG SEEAR STRENGTH OF NICKEL PLATED ZIRCALOY $-2(\mathrm{H})$

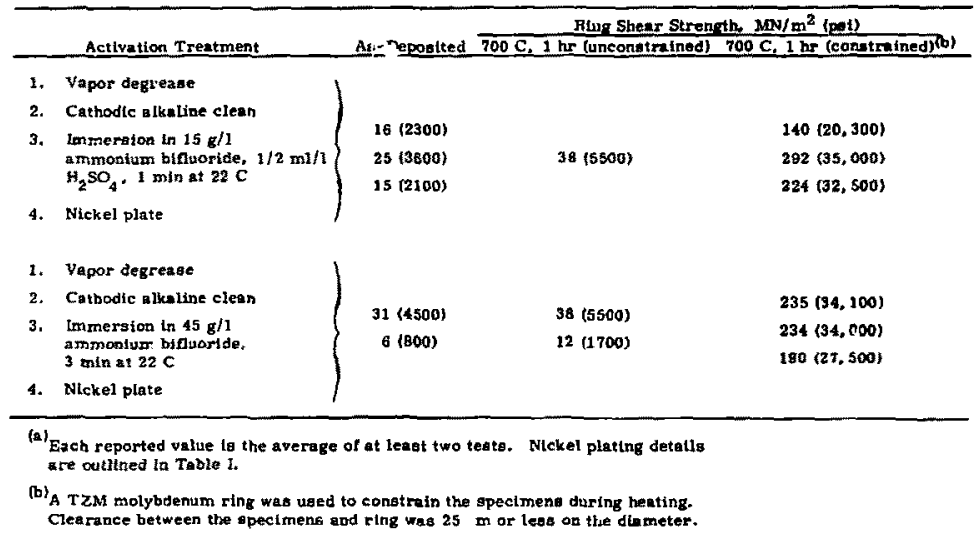




\section{Mechanical Treatments}

Mechanical treatmente such as threading or knurling were also evaluated and these produced good bond strengths (Table V). This is not aurprising inasmuch as these machining operations provide regions for "fingering" or interlocking of the plating es shown in Figure 3. Typically, 20 threads $0.13 \mathrm{~mm}$ deep were machined per centimeter. Specimens wers cleaned, pickled in HCt, and then overplated with chromium, silver, nickel, or electroless nickel costings. The highest strengths (255 MN $/ \mathrm{m}^{2}$ ) were obtained with the chromium overplaies. The values for allver and nickel were not reduced much (184 and $189 \mathrm{MN} / \mathrm{m}^{2}$, respectively). Electroless nickel showed the lowest strength $\left(122 \mathrm{lN} / \mathrm{m}^{2}\right)$. Increasing the depth of the threads from 0.13 to $0.26 \mathrm{~mm}$ prior to plating with nickel resulted in an improvement in bond strength as expected--269 vs 199 $\mathrm{MN} / \mathrm{m}^{2}$. The reason for this is that the knurl depth was only about 0.025 to $0.050 \mathrm{~mm}$ deep sompared to a depth of $0.13 \mathrm{~mm}$ for the threaded specimens. Heating knurlec or threaded specimens after plating for 2 hourg at $700 \mathrm{C}$ in an unconstrained condition did not improve the bond etrengths.

\section{TABLE V}

\section{RING SHEAR DATA FOR MECHANICAL PREPARATION} TREATMENTS FOR ZIRCALOY-2

(Each value is the average of at least three tests. Specimens were overplated with nickel per the conditions listed in Table I.)

\begin{tabular}{|c|c|c|c|}
\hline \multirow[b]{2}{*}{ Description } & \multirow[b]{2}{*}{ Process Details } & \multicolumn{2}{|c|}{ Ring Shear Strength } \\
\hline & & $\left(\mathrm{MN} / \mathrm{m}^{2}\right)$ & (psi) \\
\hline Threaded Surface & $\begin{array}{l}\text { Surface threaded, } 52 \text { threads } \\
\text { per } 2.54 \mathrm{~cm}, 0.13 \mathrm{~mm} \text { ( } 5 \mathrm{mils} \text { ) } \\
\text { deep, plated with electroless } \\
\text { nickel }\end{array}$ & 122 & 17,600 \\
\hline$n$ & $\begin{array}{l}\text { Same as above, but plated } \\
\text { with silver }\end{array}$ & 184 & 26,700 \\
\hline$n$ & $\begin{array}{l}\text { Same as above, but plated } \\
\text { with nickel }\end{array}$ & 199 & 28,800 \\
\hline$"$ & $\begin{array}{l}\text { Same as above, but threads } \\
\text { were } 0.26 \mathrm{~mm}(20 \text { mils }) \text { deep }\end{array}$ & 269 & 39,000 \\
\hline$"$ & $\begin{array}{l}\text { Same as above, but plated } \\
\text { with chromium }\end{array}$ & 255 & 37,000 \\
\hline Knurled Surface & $\begin{array}{l}\text { Knurled surface machined on } \\
\text { rod, then plated with nickel }\end{array}$ & 115 & 16,700 \\
\hline
\end{tabular}




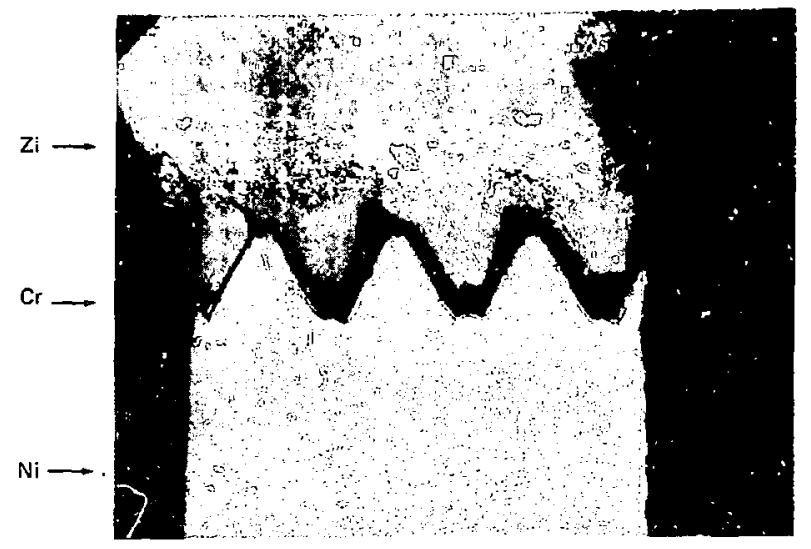

$45 x$

Figure 3. Cross Section of a Zircaloy Rod Machined With 20 Threads/cm, $0.13 \mathrm{~mm}$ Deep, Overplated With Tris Chromium and Thick Nickel, and Then Tested

\section{Summary}

A number of treatments for preparing Zircaloy-2 for plating were quantitatively evaluated by ring shear tests. When chemical activation was used, best results were obtained when the Zircaloy 2 was etched in ammonium bifluoride solution prior to nickel plating. However, even with this treatment, low and inconsistent strengths were obtained. Use of other procedures recommended in the literature gave even poorer results. A noticeable improvers $n t$ in bond strength was obtained when specimens which had been etched in ammonium bifluoride or ammonium bifluoride/sulfuric acid were heated in a constrained condition at $700 \mathrm{C}$ for 1 hour after plating. Another successful procedure consisted of threading the zirconium prior to plating. However, it is unlikely that the bonds formed by this treatment were anything other than mechanical in nature.

Based on the work described in this $f$ per, it is concluded that Zircaloy-2 could be successful'y and reliably joined to isor metals by using either añ ammonium bifluoride/sulfuric acid or ammoniuin bifluoride etch prior to nickel plating and then heating at $700 \mathrm{C}$ for 1 hour, preferably in a constrained condition. Suitable adherence for some applications could be obtained by threading or knurling the surface of the Zircaloy-2 prior to plating. 


\section{REFERENCES}

1. W. C. Schickner, J. G. Beach, and C. L. Faust, J. Electrochem. Soc. 100,289 (1953)

2. T. L. Barr, J. Vac. Sci. Techncl. 14, 660 (1977)

3. J. W. Dini and H. R. Johnson, bistals Engineering Quarterly 14, No. 1,6 (February 1974).

4. J. W. Dini and H. R. Johnson, "Electrochemisal Joining: Process, Applications, and Property Data, "SME Technical Paper AD75-855 (October 1975)

5. W. C. Schickner, J. G. Beach, and C. I. P'qust, "Surface Preparation of Zirconium for Brazing," Battelle Memorial Institute, BMI-758, July $1,1952$.

6. C. L. Faust and J. G. Beach, Plating 43 , 1134 (1956)

7. A. B. Tripler, J. G. Beach, and C. L. Faust, Battelle Memorial Institute, BMI 1097, June 21, 1956.

8. R. A. U. Huddle and O. Flint, British Patent 788, 721 (Janusry 8, 1958)

9. M. Charveriat, U. S. Patent, 3,502,549 (March 1970)

10. G. D. Kneip, Jr. and R. O. Turnbeugh, U.S. Patent $3,328,271$ (June 1967)

11. E. B. Saubestre, J. Electrochem. Soc. 106,305 (1959)

12. L. R. Kohan, Metal Finishing 57, 68 (November 1959)

13. D. E. Wax and R. L. Cowan II, U. S. Patent 4,017,368 (April 1977)

14. J. W. Dini and H. R. Johnson, Metal Finishing 72, 44 (August 1974)

15. J. W. Dini and H. R. Johnson, ASTM STP 640 (1978)

16. D. Hartshorn, Products Finishing 36, 78 (May 1972)

17. D. Wood, Metal Industry $\underline{36}, 330(1938)$ 
18. R. Seegmiller, J. K. Gore, and B. Calkins, Proc. Amer. Blectropl. Soc. 49, 67 (1962)

19. F. J. Zanner and R. W. Fisher, Welding Joumal 54, 105-8 (April 1975) 